
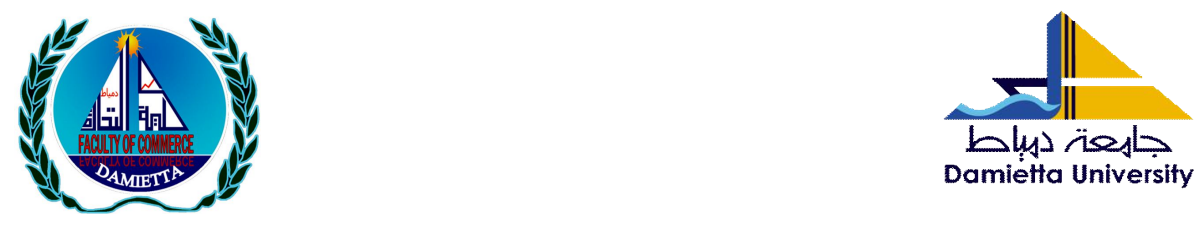

\title{
Is the Money Gap a Misleading Measurement of Excess Liquidity?
}

\author{
Prepared 6y \\ Dr. Noha Ahmed Ibrahim El-Demery \\ Lecturer of Economics at the European Universities of Egypt \\ ndemery@gmail.com
}

Scientific Journal for Financial and Commercial Studies and Researches (SIFCSR)

Faculty of Commerce - Damietta University

Vol.3, No.1, Part 1., January 2022

APA Citation:

El-Demery, N. (2022). Is the Money Gap a Misleading Measurement of Excess Liquidity? Scientific Journal for Financial and Commercial Studies and Research, Faculty of Commerce, Damietta University, 3(1)1, pp.447-458.

Website: https://cfdi.journals.ekb.eg/ 
Scientific Journal for Financial and Commercial Studies and Researches

(SJFCSR) Faculty of Commerce - Damietta University

\title{
Is the Money Gap a Misleading Measurement of Excess Liquidity?
}

\author{
Dr. Noha Ahmed Ibrahim El-Demery
}

\begin{abstract}
Liquidity status can impact monetary policy decisions and therefore the macroeconomic framework as a whole. This highlights the importance of accurately defining the liquidity status of the economy at any point of time. The 'money gap' concept is gaining attention and being employed to measure excess liquidity. The purpose of this article is to investigate whether the 'money gap' in this regard is reliable or not. Our methodology consisted of two stages. The first was a critical literature review of the different interpretations of the 'money gap'. The review revealed that; the money gap, as a measurement of excess liquidity, is misleading. This is because, it benchmarks liquidity status to a base period or to long term equilibrium; both benchmarks don't reflect the current macroeconomic needs. Therefore, we moved to stage two; we developed a framework of analysis to inform monetary authorities, in inflation targeting regimes, regarding current liquidity status. This framework didn't only consider the Marshallian K, in liquidity analysis, as established in literature, but also, originally, simultaneously considered the inflation level relative to the target. This is through linking the different possible values of the Marshallian $\mathrm{K}$ to the different possible levels of inflation in an inflation targeting regime. Such linkage enabled to classify, within each liquidity status, different levels of inflationary pressures. This framework can help monetary authorities, in inflation targeting regimes; accurately timely define liquidity status and the relative level of inflationary pressures, this is to make accurate timely policy choices, especially needed in crisis time.
\end{abstract}

JEL Classification : E410 ; E520; E610.

Keywords: velocity of money; inflation targeting; interest rates; monetary policy; macroeconomic policy coordination. 


\section{Dr. Noha Ahmed Ibrahim El-Demery}

\section{Introduction}

With the Coronavirus spread and the lockdown; many countries find themselves in need for liquidity to stimulate the market. They also need liquidity to help the fragile and to protect the vulnerable, in both the household sector and the business sector. The first step then, is accurately define the country liquidity status; whether the country is encountering domestic excess liquidity or domestic liquidity shortfall. This is in order to take the right policy measures.

Excess liquidity may make, in an inflation targeting regime, the monetary authority increases the policy rate ${ }^{1}$. This may discourage investors, constituting then a handicap for the market stimulation objective. Furthermore, increasing the policy rate, will increase the government domestic debt service, reducing then the government fiscal space and hence its capacity to stimulate the market, protect the vulnerable and help the fragile. As for liquidity shortfall, it may induce lowering the policy rate which may encourage investors, and therefore stimulate the market. Moreover, decreasing the policy rate will decrease the government domestic debt service, increasing then the government fiscal space, hence its capacity to realize its objectives.

The researchers concern for liquidity status impact has not been limited to the impact of domestic liquidity; there has been a rising concern with the impact of global liquidity (Rüffer and Stracca, 2006; Baks and Kramer, 1999). Rüffer and Stracca (2006) have concluded that; excess liquidity is a useful indicator of inflationary pressures at a global level and therefore merits attention in the same way as the level of interest rates, if not possibly more.

In this article, we are concerned with domestic liquidity status. This is because, in crisis time, especially international ones, domestic liquidity is essential to help the country out. We focused on liquidity status in an inflation targeting because inflation targeting is increasingly being adopted by Central Banks around the world.

1 The policy rate is the monetary authority instrument in an inflation targeting regime. 
Scientific Journal for Financial and Commercial Studies and Researches

(SJFCSR) Faculty of Commerce - Damietta University

Excess liquidity, as Rüffer and Stracca (2006) have recalled, is the ratio of a monetary aggregate $(\mathrm{M})$ to nominal gross domestic product (GDP). This ratio is also known as the 'Marshallian K', which is equivalent to the inverse of the velocity of money. The two terms 'Marshallian K' and 'inverse velocity' are used interchangeably in this article. Aside the Marshallian K, the money gap concept is gaining attention and is being employed to measure excess liquidity, especially in the euro area (Dufrénot et al., 2014; European Central Bank, 2001). The question that follows; is the money gap a reliable measurement of excess liquidity? And if not, what is the alternative?

To answer these questions, our methodology consisted of first; a critical review of the money gap interpretations in literature, which showed that the money gap is neither necessary nor sufficient to define current liquidity status. Second; in order to have a framework to detect liquidity status in an inflation targeting regime; we originally linked the different possible levels of the Marshallian $\mathrm{K}$ to the different possible levels of inflation, in an inflation targeting regime. Then, in discussion, to give an example of how the proposed framework can be applied in reality; we explained the monetary policy decisions in Egypt, during the Coronavirus, in light of this framework. The article concludes with policy implications and finally; signals future research perspectives.

\section{Methodology}

\section{A critical literature review}

In literature, one of the interpretations of the money gap ${ }^{1}$ has been concerned with the linkage between the money gap and 'sustainable output'. Sustainable output, in this context, has been defined as the amount of goods and services produced when the economy is producing with no inflation over the long-term. According to this interpretation, if we acknowledge a long-term relationship between money growth and nominal spending, then it would follow that there exists a quantity of money in circulation required for sustainable output to be achieved. In this case, the money gap is the difference between actual money growth and the money growth consistent with the desired output growth.

${ }^{1}$ Institute of International Monetary Research. https://mv-pt.org/the-money-gap/ 


\section{Dr. Noha Ahmed Ibrahim El-Demery}

We put this interpretation of the money gap in question, by asking, is the 'sustainable output with no inflation' desirable? No inflation means, according to Philips's curve, a stable unemployment rate i.e., some people who can and are willing to work will not find jobs, which is an undesirable situation, especially on the social level. Within such interpretation of the money gap, the monetary policy would be acting to reach an equilibrium that would keep some people who can and are willing to work unemployed. That is why; the article doesn't refer to such interpretation of the money gap to measure excess liquidity.

Another interpretation of the money gap in literature has been defined by the European Central Bank (ECB) (June 2001). The ECB (June 2001) has measured excess liquidity through an estimate of a nominal or real money gap reflecting the deviation of the actual stock of broad money from a level in line with the reference value for broad money growth in nominal and real terms respectively, starting from a somewhat arbitrary base period. The real money gap corresponds to the nominal money gap less the deviation of the Harmonized Index of Consumer Prices from the ECB (June 2001)'s definition of price stability embedded in the derivation of the reference value. The ECB (June 2001) has explained that the somewhat arbitrary choice of the base period requires that the interpretation of the real money gap should concentrate more on the change in the gap rather than on its level.

According to the ECB (June 2001), such measures of excess liquidity, like the nominal money gap and the real money gap, are useful for a medium term oriented monetary analysis. This is because, these measures ensure that past excessive or weak monetary growth which is no longer visible in the annual growth rate of broad money, but which may still contain information about risks to price stability, is taken into account (ECB, June 2001). This opened a question for our article; what about short-term monetary analysis? We can't rely on estimates of the nominal money gap to identify liquidity status in the short term. This is because, when we referred to the ECB (June 2001) interpretation of the money gap, we found that, all other things being equal, there are three possibilities:

1- If the actual stock of broad money $>$ broad money reference value for growth starting from a somewhat arbitrary base period, then the 
Scientific Journal for Financial and Commercial Studies and Researches

(SJFCSR) Faculty of Commerce - Damietta University

nominal money gap is positive. But our article put forward that; if current $\mathrm{M} / \mathrm{GDP} \leq 1$ i.e., if current Marshallian $\mathrm{K} \leq 1$ then the positive gap is not reflecting current excess liquidity i.e., we can't say that there is current excess liquidity in the market unless M/GDP $>1$.

2- If the actual stock of broad money $<$ broad money reference value for growth starting from a somewhat arbitrary base period, then the nominal money gap is negative. But our article put forward that; if current $\mathrm{M} / \mathrm{GDP} \geq 1$ then the negative gap is not reflecting current liquidity shortage i.e., we can't say that there is current liquidity shortage in the market unless $\mathrm{M} / \mathrm{GDP}<1$.

3- If the actual stock of broad money $=$ broad money reference value for growth starting from a somewhat arbitrary base period, then the nominal money gap is zero. But we put forward that; we can't say that the market is currently neither in need nor in shortage for liquidity unless $\mathrm{M} / \mathrm{GDP}=1$.

The three possibilities show that; the Marshallian K better indicates current liquidity status rather than the nominal money gap. The nominal money gap is neither necessary nor sufficient to define current liquidity status, so by definition the real money gap also is not helpful in this regard. We took the analysis a step forward and constructed a framework to detect liquidity status in an inflation targeting regime.

Linking the Marshallian $K$ level to the different inflation levels in an inflation targeting regime

Although, as shown above, we can refer to the Marshallian K to detect liquidity status; in inflation targeting regimes, including the inflation target in the monetary analysis makes the analysis more insightful. Therefore, we established the linkage between the different possible values of the Marshallian K 'denoted k' and the different possible inflation levels relative to the inflation target. This enabled us, all other things being equal, to classify within each liquidity status different levels of inflationary pressures; as follows:

\section{1- If $\mathrm{K}>1$; there are three possible cases:}

Case 1: If $K>1$ and inflation rate $>$ the target; then there is excess liquidity in the market signaling inflationary pressures. The monetary policy is expected to increase the policy rate. 


\section{Dr. Noha Ahmed Ibrahim El-Demery}

Case 2: If $\mathrm{K}>1$ and inflation rate=the target; then there is excess liquidity in the market. But, having the inflation rate at the target reduces inflationary pressures relative to case 1 .

Case 3: If $K>1$ and inflation rate $<$ the target; then there is excess liquidity in the market. But, having the inflation rate below the target reduces inflationary pressures relative to case 2 .

\section{2- If $K<1$; there are three possible cases:}

Case 4: If $\mathrm{K}<1$ and inflation rate $<$ the target; then there is liquidity shortfall in the market signaling disinflationary pressures. The monetary policy is expected to lower the policy rate.

Case 5: If $K<1$ and inflation rate=the target; then there is liquidity shortfall in the market. But, having the inflation rate at the target reduces disinflationary pressures relative to case 4 .

Case 6: If $K<1$ and inflation rate $>$ the target; then there is liquidity shortfall in the market. But, having the inflation rate beyond the target reduces disinflationary pressures relative to case 5 .

\section{3- If $K=1$; there are three possible cases:}

Case 7: If $K=1$ and inflation rate=the target; then there is neither excess liquidity nor liquidity shortfall in the market. There are no inflationary pressures related to liquidity status.

The monetary policy shall be very prudent in order not to deviate from the target; unless the monetary policy needs to revise its inflation target.

Case 8: If $K=1$ and inflation rate $>$ the target; then there is neither excess liquidity nor liquidity shortfall in the market. But, if the monetary policy increases the policy rate to reach the target, this will lead to liquidity shortfall and disinflationary pressures.

Case 9: If $K=1$ and inflation rate $<$ the target; then there is neither excess liquidity nor liquidity shortfall in the market. But, if the monetary policy lowers the policy rate to reach the target, this will lead to excess liquidity and inflationary pressures. 
Scientific Journal for Financial and Commercial Studies and Researches

(SJFCSR) Faculty of Commerce - Damietta University

\section{Discussion}

To show how, as suggested in the framework proposed above, considering both the Marshallian K level and the inflation level relative to the target, in an inflation targeting regime, to define the current liquidity status, can help have a flexible responding monetary policy, one which is consistent with the macroeconomic context and objectives; we take an example of the Egyptian economy during the coronavirus surge. This is without claiming that the Central Bank of Egypt (CBE) reasoned the way we propose.

The coronavirus crisis was and still stressing on the Egyptian public finance. With the Coronavirus spread and the lockdown; many countries, among which Egypt, find themselves in need for liquidity to stimulate the market, help the fragile and protect the vulnerable.

In Egypt, before and after the Corona crisis started ${ }^{1}$, inflation rate was below target 9\% (+/-3\%) (since June 2019) and inverse velocity was below one. Therefore, we had case 4 of the framework we proposed; where $\mathrm{K}<1$ and inflation rate $<$ the target, i.e., there was liquidity shortfall in the market and it was expected that the CBE lowers the policy rate.

Indeed, the first cut of the policy rate by the $\mathrm{CBE}$, after the Coronavirus took effect, was in March 2020 by 3\%. The second cut was in September 2020 by $0.5 \%$ and the third was in November 2020 by another $0.5 \%$. On the fiscal policy level, every $1 \%$ cut in the policy rate was estimated to provide LE 8-10 billion of fiscal savings ${ }^{2}$ giving then more maneuvers for the fiscal policy. On another front, such reductions, all other things being equal, would encourage investments, with the lockdown being contained, and therefore would stimulate growth. Moreover, a decrease in interest rates would, all other things being equal, discourage capital inflows which would depreciate the local currency and therefore support exports, reduce the trade deficit and further support growth.

Clarifying in terms of supply and demand; inverse velocity was increasing in Egypt over December 2019-July 2020 which reflected

${ }^{1}$ The Central Bank of Egypt.

${ }^{2}$ The Ministry of Finance of Egypt financial statement of 2019/20. 


\section{Dr. Noha Ahmed Ibrahim El-Demery}

liquidity availability enhancement in the market. An increasing inverse velocity means that velocity has been decreasing hinting to a decreasing money demand. As liquidity availability was enhancing and money demand was decreasing, it was anticipated a reduction of the policy rate. This is since, on one hand, the increased inverse velocity remained less than one, reflecting no-excess liquidity in the market, and on the other hand, inflation rate remained below the target.

\section{Conclusion and Policy Implications}

A critical review of the literature interpretations of the money gap showed that the money gap as a measurement of excess liquidity is misleading. This is because it benchmarks liquidity status to an arbitrary historic base period or to long term equilibrium, while both benchmarks don't reflect the current economic situation needs. Therefore, relying on the money gap as an indicator of liquidity status, can lead to misappropriated monetary policy decisions, that wouldn't support current macroeconomic successful performance in terms of growth, inflation targeting and in terms of consistency and coordination between macroeconomic policies.

The Marshallian k i.e., inverse velocity which measures the actual ratio of a monetary aggregate to nominal GDP informs us about current liquidity status. Referring to the current liquidity status through measuring the Marshallian $\mathrm{K}$ and accordingly updating the monetary policy decisions would give the monetary policy more flexibility to respond to current economic conditions and occurring shocks.

The framework we proposed, originally established the relation between on one hand, the different possible values of the Marshallian K and on the other hand, the actual inflation level relative to the inflation target. Linking the Marshallian $\mathrm{K}$ to the actual inflation level enabled us to classify within each liquidity status different levels of inflationary pressures. Such framework and such classification will help the monetary authority, in an inflation targeting regime, take its decisions, while considering both factors; liquidity status and inflation target, and while being informed about the relative level of inflationary pressures. 
Scientific Journal for Financial and Commercial Studies and Researches (SJFCSR) Faculty of Commerce - Damietta University

Further research is needed. In this article, we only considered liquidity status relative to the needs of the markets captured by the national income account measure of output and prices, taking then into consideration only inflationary pressures emanating from these markets. Schinasi and Hargraves (1993) have explained that there are potential inflation pressures in markets not captured by national income account measures of output and prices; especially when there is a substantial shift in the pattern of transactions toward assets and other markets not captured in national income measures of final goods transactions. Further research is needed then to identify inflationary pressures in markets not captured by national income account measure of output and prices. This identification is useful, as Schinasi and Hargraves (1993) have clarified, for exploring the role that the monetary policy may have played in these markets. We add that such identification is also useful to explore the role that these markets may have played as sources of inflationary pressures.

\section{References}

Baks K. and Kramer C., 1999, 'Global Liquidity and Asset Prices: Measurement, Implications and Spillovers', International Monetary Fund, Working Paper No. 168.

Central Bank of Egypt www.cbe.org.eg

Dufrénot, Gilles et al., 2014, 'Which of the real money gap or nominal money gap helped predict inflation in Europe? A retrospective analysis', Banks and Bank Systems, Volume 9, Issue 3.

European Central Bank, June 2001, Monthly Bulletin.

Institute of International Monetary Research https://mv-pt.org/themoney-gap/

Ministry of finance of Egypt www.mof.gov.eg

Rüffer, Rasmus and Stracca, Livio, November 2006, 'What is Global Excess Liquidity, and Does it Matter?', European Central Bank, Working Paper Series No. 696.

Schinasi G. J. and Hargraves M., 1993, 'Boom and Bust in Asset Markets in the 1980s: Causes and Consequences', in Staff Studies for the World Economic Outlook, International Monetary Fund. 


\title{
Dr. Noha Ahmed Ibrahim El-Demery
}

\section{هل الفجوة النقديتمقياس مضلل للسيولتمالزائدة؛}

\author{
نهى أحمد إبراهيم الدميرى \\ مدرس اقتصاد فى الجامعات الأوربية في مصر.
}

يمكن أن يؤثر مستوى السيولة على قرارات السياسة النقدية وبالتالي على الاقتصاد

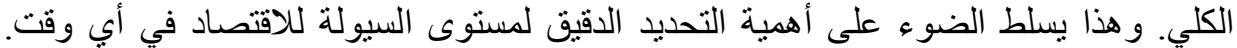

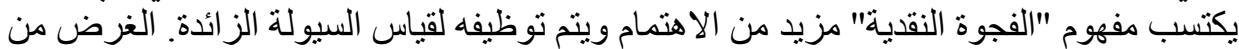

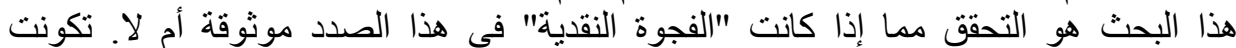

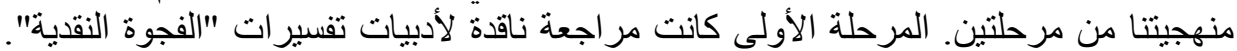

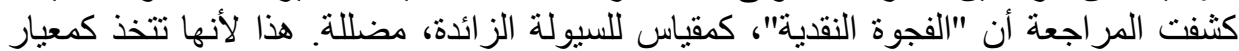

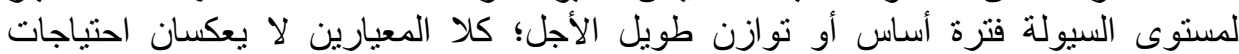

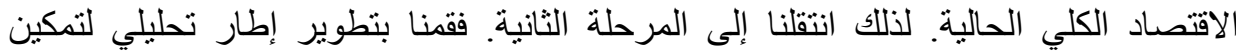

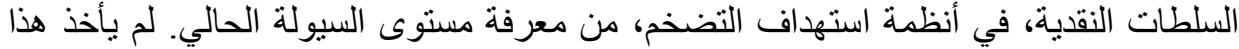

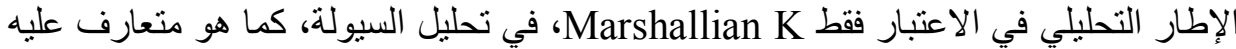

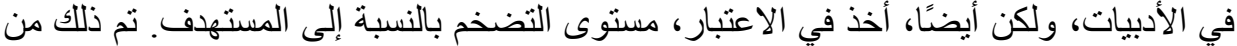

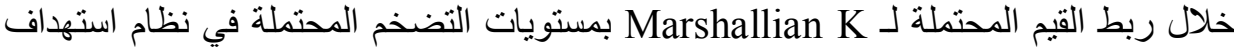

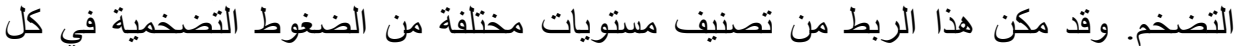

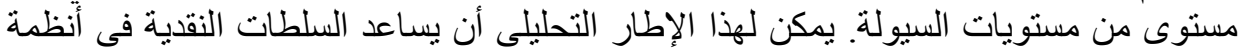

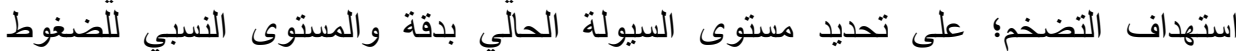
التضخمية، وذلك لاتخاذ خبارات سياسية دقيقة في الوقت المناسب، ولا سيما في أوقات التئي

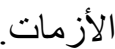

التصنيف وفقال ELLE: E410؛ E620؛ E610. الكلمات الرئيسيتّ: سرعة دوران النقود؛ استهداف التضخم؛ اسعار الفائدة؛ السياسة النقديـة؛ التنسيق بين سياسات الاقتصاد الكلي. 